\title{
Pretransplant echocardiographic findings as predictors of late adverse outcomes following liver and kidney transplantation
}

\author{
(1D)Zrinka Sertić ${ }^{1 *}$, \\ (D)Tomislav Letilović1,2, \\ DMladen Knotek ${ }^{1,2}$, \\ (DTajana Filipec \\ Kanižaj ${ }^{1,2}$, \\ (D)Mario Stipinović \\ (DDarko Počanić ${ }^{\text {, }}$ \\ (D)Inga Starovečki', \\ (D)Darko Vujanić ${ }^{2}$, \\ (DHelena Jerkić \\ 'University of Zagreb, School \\ of Medicine, 10000 Zagreb, \\ Croatia \\ ¿University Hospital "Merkur", \\ Zagreb, Croatia
}

KEYWORDS: liver transplantation, kidney transplantation, mitral regurgitation, tricuspid regurgitation, aortic stenosis.

CITATION: Cardiol Croat. 2019;14(9-10):232. | https://doi.org/10.15836/ccar2019.232

*ADDRESS FOR CORRESPONDENCE: Zrinka Sertić, Medicinski fakultet, Šalata 3, HR-10000 Zagreb, Croatia. Phone: +385911605083 / Email: zsertic@hotmail.com

ORCID: Zrinka Sertić, https://orcid.org/0000-0002-4534-4283 • Tomislav Letilović, https://orcid.org/0000-0003-1229-7983 Mladen Knotek, https://orcid.org/0000-0002-4989-9147 • Tajana Filipec Kanižaj, https://orcid.org/0000-0002-9828-8916 Mario Stipinović, https://orcid.org/0000-0002-1582-1552 • Darko Počanić, https://orcid.org/0000-0003-3257-110X Inga Starovečki, https://orcid.org/0000-0002-7810-3427 • Darko Vujanić, https://orcid.org/0000-0003-0585-5887 Helena Jerkić, https://orcid.org/0000-0002-1650-4735

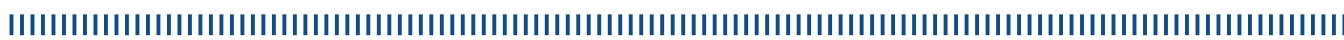

Introduction: Transthoracic echocardiography (TTE) is recommended as the standard of care in evaluation of cardiovascular (CV) disease in liver (LT) and kidney (KT) transplant candidates., ${ }^{1,2}$ Guidelines for preoperative CV assessment are oriented at the immediate perioperative period and non-ischemic CV processes that would predict poor outcomes after LT and KT are defined less clearly. Aim: to establish whether $\geq$ moderate mitral (MR), tricuspid regurgitation (TR) or $\geq$ mild aortic stenosis (AS) on pretransplant TTE are associated with mortality, graft survival or major CV adverse events (MACE) in the late postoperative period (>30 days)

Patients and Methods: Patients were stratified into cohorts based on the presence of $\geq$ moderate MR, TR and $\geq$ mild AS. Exclusion criteria was loss to follow up, incomplete TTE findings and death within 30 days of transplantation. MACE were defined as stroke, myocardial infarction (MI) or heart failure. Patient survival was defined as time from transplantation to death or last follow-up and graft survival as time from transplantation to last follow-up, death, graft dysfunction or re-transplantation. Outcomes of interest were compared between cohorts via logistic or Cox regression.

Results: 306 LT (median age 59, IQR 53-64) and 196 KT patients were included (median age 52, IQR 4061). Median follow up was 36 months for LT (range 14.3 - 55.9), 40,5 months for KT (range 18-64.9). MACE occurred in $4.25 \% \mathrm{LT}$ and $4.59 \% \mathrm{KT}$ recipients. Upon univariate analysis AS was associated with MACE in KT recipients but crossed the significance level after adjusting for common confounders (age, sex, hypertension, diabetes, smoking). $11.76 \% \mathrm{LT}$ and $9.69 \% \mathrm{KT}$ recipients died. The most common cause of death was sepsis. MR was found to be associated with LT patient survival, but the association was lost after adjusting for age. In an age adjusted model MR was found to be associated with KT patient survival (HR 2.97, 95\% CI 1.06-8.26, P=0.037). Graft survival was not associated with any potential predictors.

Conclusion: Associating TTE findings with adverse outcomes after LT and KT might help distinguish patients who would benefit from closer management in the late postoperative period. Moderate or more severe MR was found to be associated with late mortality in KT recipients, however the significance of this is yet to be determined in larger sample studies.

\section{RECEIVED:}

July 12, 2019

ACCEPTED:

September 16, 2019

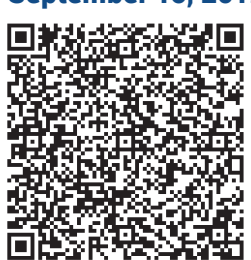

$\square$ Cardiologia Croatica $2019 ; 14(9-10): 232$.

LITERATURE IIIIIIIIIIIIIIIIIIIIIIIIIIIIIIIIIIIIIIIIIIIIIIIIIIIIIIIIIIIIIIIIIIIIIIIIIIIIIIIIIIIIIIIIIIIIIIIIIII

1. Lentine KL, Costa SP, Weir MR, Robb JF, Fleisher LA, Kasiske BL, et al; American Heart Association Council on the Kidney in Cardiovascular Disease and Council on Peripheral Vascular Disease. Cardiac disease evaluation and management among kidney and liver transplantation candidates: a scientific statement from the American Heart Association and the American College of Cardiology Foundation. J Am Coll Cardiol. 2012 Jul 31;60(5):434-80. https://doi.org/10.1016/j.jacc.2012.05.008

2. European Association for the Study of the Liver. EASL Clinical Practice Guidelines: Liver transplantation. J Hepatol. 2016 Feb;64(2):433-485. https://doi.org/10.1016/j.jhep.2015.10.006 